\title{
Selection of Façades Finishing Technology for a Commercial Building Using Multi-Criteria Analysis
}

\author{
Agnieszka Leśniak, Jakub Balicki
}

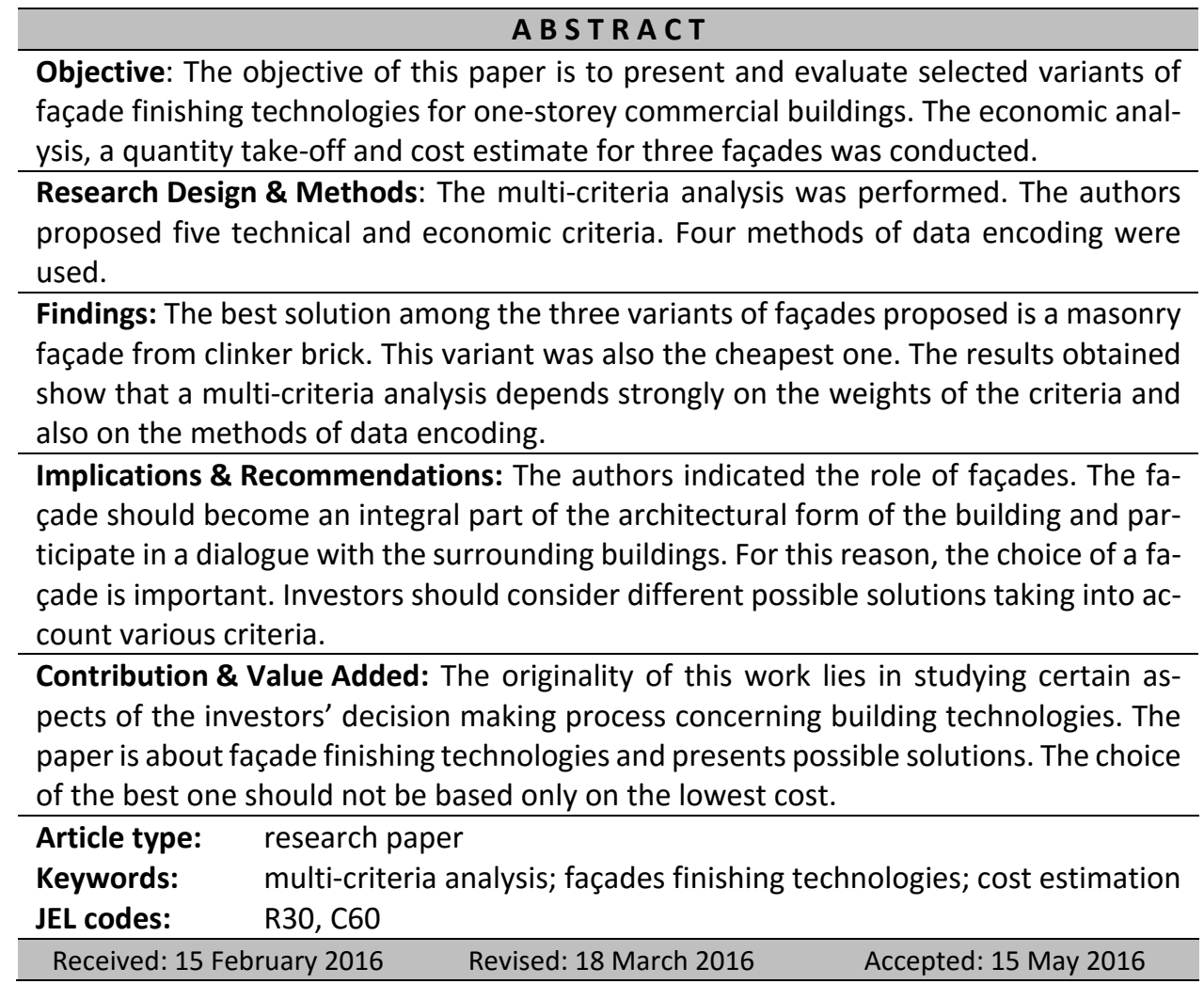

\section{Suggested citation:}

Leśniak, A., \& Balicki, J. (2016). Selection of Façades Finishing Technology for a Commercial Building Using Multi-Criteria Analysis. Entrepreneurial Business and Economics Review, 4(2), 67-79, DOI: http://dx.doi.org/10.15678/EBER.2016.040206 


\section{INTRODUCTION}

Façades should create an integral part of the architectural form of the building. Because of the fact that facades are judged by a large collection of observers, they constitute one of the most important parts of the building. The first impression formed after looking at the façade of the building significantly influences the further perception of the building. The façade can participate in a dialogue with the surrounding buildings or provide an independent entity detached from the environment in which it is located.

Crum (1973) describe a façade as the external wall of the building with all elements appearing on it. Moreover, he suggests that façades, together with the roof, are the synonym of the building external envelope designed to fulfil this role for about 20 years of the expected lifetime. Over the centuries, styles of building finishing have evolved but façades were still heavily influencing the development of the interior until the time of modernism when, according to the contemporary trends, designers decided to break with this approach. Nowadays, it ever-frequently happens that builders are trying to turn their buildings into new symbols and characteristic points of the city without taking into account their function and the surrounding environment. For this reason, for centuries the issue has aroused controversy, not only among designers and builders, but also among ordinary people who are the users and observers of the surrounding buildings.

The purpose of this article is the presentation and evaluation of selected variants of façade finishing technologies - the older and more well known, as well as the modern and not so popular ones. The authors decided to carry out a technical and economic analysis on the example of a commercial building. A multi-criteria analysis based on selected criteria that point out the most appropriate façade finishing technology for the building was conducted.

\section{BUILDING FAÇADE: FUNCTIONS AND TYPES}

According to Komar and Tymkiewcz (2006), one can distinguish three main functions of the façade:

1. Protection and shielding. The function of the façade that is of vital importance involves the protection of the interior against unfavourable environmental factors. The needs associated with this function have changed over the centuries. In the Middle Ages it was necessary to protect buildings against invaders' attacks. Therefore, the crucial buildings had massive form with thick walls and small openings for shooters. Today, the main purpose of the construction industry concerning façades is to improve such parameters as thermal transmittance, fire resistance and proper acoustics.

2. Information. In the case of informational features of façades, they should first of all enable the identification of the main functions of the facility and also cause feelings appropriate to that function (Bojęś, 2000). It is also welcome when the façade gives the onlooker the ability to estimate the time in which the building was built. A clearly defined style in which the building is erected can help with that. The façade should express the prestige and status of the building and the social position of its owner. Therefore, in the case of a public building, such as the court, the façade can usually be 
expected to be quite simple and in subdued colours. On the other hand, in the case of an office centre, a complex form and large plates of glass are typically most expected.

3. Aesthetics. Façades play a representative role; they are a kind of the 'packaging', so that the building attracts the attention of potential buyers or tenants. The aesthetic quality of the building is built primarily by the structure form, the placement and size of windows, as well as the appropriate selection of colours and properly matched details. One cannot forget about the proper state of repair which has a crucial influence on the perception of the building.

The contemporary façade can be divided into five main groups, as shown on Figure 1.

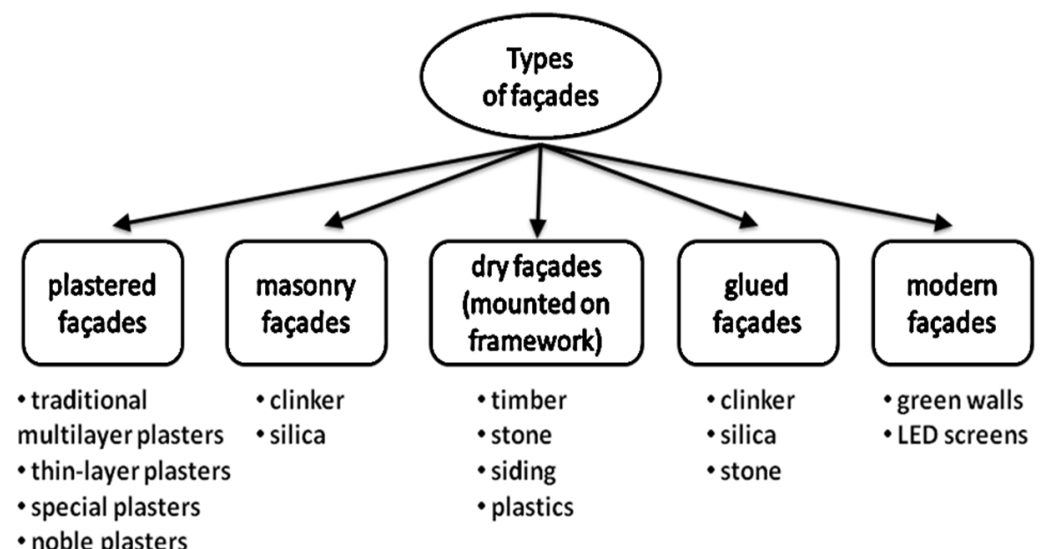

Figure 1. Types of façade

Source: own research based on (Bojęś, 2000; Komar \& Tymkiewcz, 2006).

External plasters act as a barrier against negative external influences - humidity, rainfall, temperature changes, UV radiation and chemical attack. They improve thermal insulation properties and the aesthetics of the building. Plasters protect walls against mechanical damage and fire. A basic division of plasters may be conducted with regard to the type of the binder used, thickness and method of applying.

Even though masonry facades have been known for centuries, they do not lose their popularity and are still very often used for finishing buildings. The reasons for this are numerous advantages of bricks (e.g. consist of natural materials, require very little maintenance).

Dry façades, mounted on the framework, can be divided according to the material used. Timber façades are one of the oldest methods of protecting exterior walls. The lifetime of wood depends largely on its resistance to fungi and insects. As a result, regardless of the type of wood used on the façade, all wooden elements that will be used should be first impregnated with preparations protecting against moisture, fungi and fire. Façades made of any kind of stone, whether natural or artificial ones, are genuinely decorative and create an attractive image of a building. For this reason, stone façades are mostly designed for representational fragments of building façades (Young et al., 2003). Siding was very popular in Poland in the 1990s. Although it has become relatively out of fashion, it is still 
a popular choice for both new buildings and renovating old ones. Plastic panels are becoming more and more popular nowadays. Their use enables courageous architectural concepts, while maintaining costs under adequate control and providing short realisation time. Panels are available in a variety of formats; they are characterised by the ease of installation and maintenance, fire resistance, durability and exceptional resistance to atmospheric conditions.

Currently, glued façades are increasingly replacing those made of brick and stone. This is caused by the fact that tiles are much thinner and lighter than bricks. The façades made of tiles are suitable for both new and older buildings which are being renovated. The plates, depending on the material from which they are made, may have a smooth or rough surface. Tiles can be laid on the walls of cellular concrete, reinforced concrete and walls finished with lime-cement plaster. They can also be placed on polystyrene and cementfibre boards.

Modern façades classes include green walls (Kibert, 2008; Perini \& Rosasco, 2013; Zieba et al., 2013; and LED screens (Schoch, 2006; Wiethoff, 2012). Green walls can reduce temperature fluctuations at the surface of the wall and, as a result, reduce the flow of heat between the walls of the building. This reduction is caused primarily by creating a buffer against wind during winter months, trapping a layer of air within the plant mass and reducing ambient temperature via evapotranspiration and shading. LED light is becoming increasingly appreciated and used in architecture. The building façade can be transformed into a multimedia screen on which one can create dynamic lighting scenarios, inscriptions and logos.

Careful designing of a building façade is one of the most important methods of saving energy (Shameri at al., 2011). Energy consumption, thermal comfort and condensation for a typical office building depend on the facade system (Hien at al., 2005; Gratia \& De Herde, 2007). The worldwide fast development of building-integrated solar technology has prompted the design alternatives of fixing the solar panels on the building façades (Chow et al., 2007).

\section{SELECTED VARIANTS OF FAÇADE FINISHING TECHNOLOGIES FOR THE COMMERCIAL BUILDING}

The authors proposed a one-storey commercial building for which it would be possible to compare selected technologies of façade finishing. Three variants of façade finishing technologies were prepared:

- Variant I - a masonry façade from clinker brick. Clinker brick was selected for comparison because it is now very popular both in the case of new buildings and restored ones. This material and its properties are well known to investors. They often choose it because of its very good thermal parameters and the aesthetic value. The clinker wall, together with a load-bearing wall, thermal insulation and ventilation gap, forms a multilayer wall.

- Variant II - a dry façade from concrete brick. The system consists of a supporting structure fixed to the load-bearing wall and a layer of concrete bricks supported by the framework. The supporting structure may be made of steel, steel combined with wood, wood or aluminium. Between the load-bearing wall and the concrete brick layer there is enough space where one can put thermal insulation and provide a ventilation gap. 
- Variant III - a dry façade from composite panels. The system consists of a supporting structure made of aluminium profiles and composite panels. The panel consists of two layers of aluminium permanently connected with the core made of the mixture of polyethylene and aluminium hydroxide or mineral filler. The entire structure of the façade is characterised by its low weight. Panels may be mounted to the framework vertically or horizontally.

\section{Cost Estimation of the Proposed Variants of Façade Finishing Technologies}

Bills of quantities for the selected variants were prepared according to catalogues: KNR 202 (for variant I), NNRNKB 2-02 (for variant II) and KNR 18 (for variant III) used by analogy. The amount of works was the same in all variants $-191.70 \mathrm{~m}^{2}$.

Financial basis used for calculations :

- Labour cost (R) - 20 PLN/w-h.

- Materials (M) and equipment (S) prices were taken from the market or the price publications. Costs of purchases of materials are included in the prices of materials.

- Indirect costs $(K p)-60 \%(R+S)$.

- Profit (Z) - $20 \%(R+S+K p)$.

The results of cost estimation are shown in Table 1 and Figure 2.

Table 1. Summary of the cost calculation for the selected variants of building façades

\begin{tabular}{|l|c|c|c|c|}
\hline \multicolumn{1}{|c|}{ Variant } & Reference to catalogue & $\begin{array}{c}\text { Quantity } \\
\text { of works } \\
{\left[\mathbf{m}^{2}\right]}\end{array}$ & $\begin{array}{c}\text { Unit } \\
\text { price } \\
{[\text { [PLN] }}\end{array}$ & $\begin{array}{c}\text { Estimated } \\
\text { costs } \\
\text { [PLN] }\end{array}$ \\
\hline $\begin{array}{l}\text { Variant I } \\
\text { masonry façade from } \\
\text { clinker brick }\end{array}$ & KNR 202/103/4 (by analogy) & 191.70 & 278.86 & $53,457.26$ \\
\hline $\begin{array}{l}\text { Variant II } \\
\text { dry façade from concrete } \\
\text { brick }\end{array}$ & $\begin{array}{c}\text { KNR 202/2007/4 (by analogy) } \\
\text { NNRKB 202/2141/3 } \\
\text { (by analogy) }\end{array}$ & 191.70 & 304.97 & $58,463.68$ \\
\hline $\begin{array}{l}\text { Variant III } \\
\text { dry façade from compo- } \\
\text { site panels }\end{array}$ & $\begin{array}{c}\text { KNR } 18 / 2611 / 1 \text { (by analogy) } \\
\text { KNR } 18 / 2613 / 3(1) \\
\text { (by analogy) }\end{array}$ & 191.70 & 475.91 & $91,233.07$ \\
\hline
\end{tabular}

Source: own research.

When analysing Table 1 and Figure 2, it can be seen that the difference in cost is not significant between variants I and II, and amounts to $9 \%$. The cheapest is the façade made of clinker bricks and the most expensive one is variant III: a dry façade from composite panels. The unit cost of façades per $1 \mathrm{~m}^{2}$ is presented in Figure 3.

The direct costs of the execution of the selected façade finishing technologies are presented in Figure 4. A slight difference in cost between clinker brick and concrete brick follows mainly from higher labour required in the case of dry façade from concrete brick technology (PLN 10,952.97), while the cost of materials is almost the same for both. It is easily noticeable, however, that the main cost generating factor in the case of composite panel technology is the cost of materials (PLN 74,878.02), exceeding the same type of 


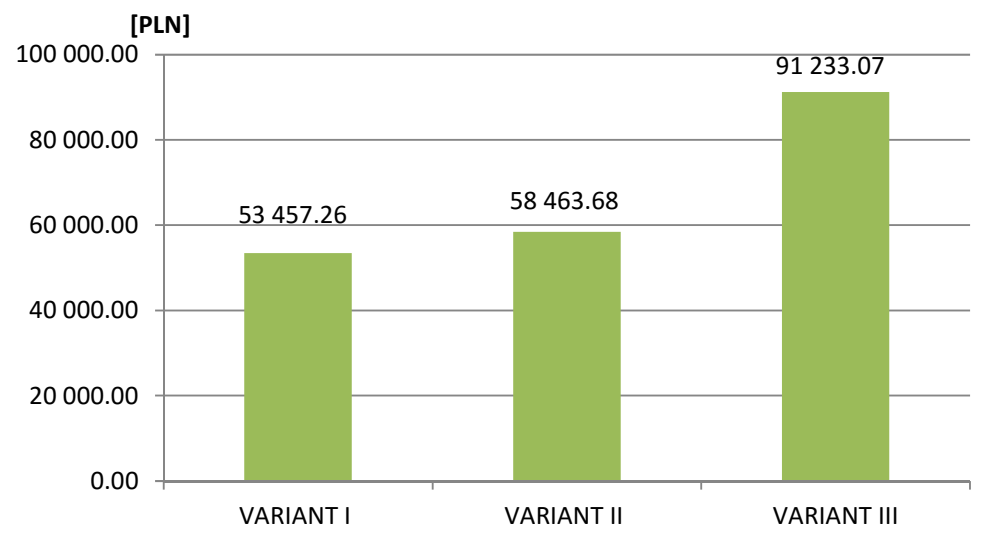

Figure 2. Comparison of the total costs for selected façade finishing technologies Source: own research.

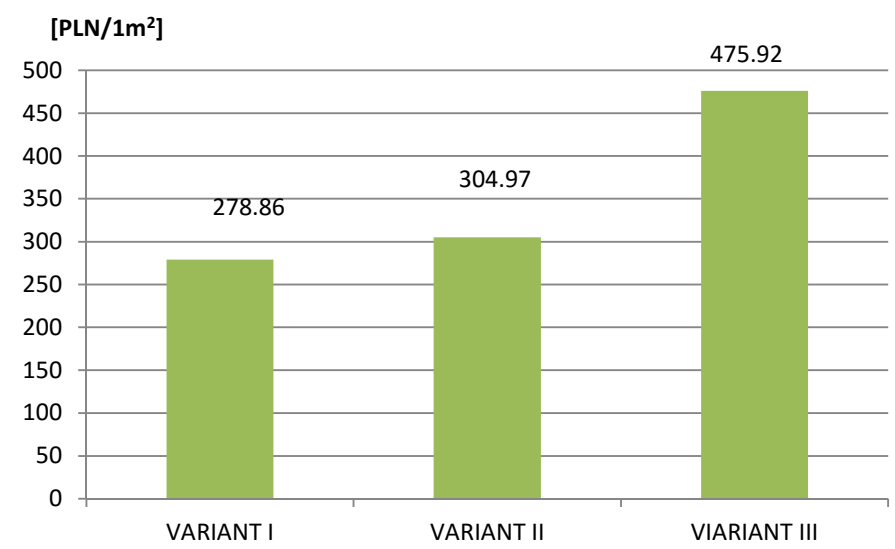

Figure 3. Comparison of the unit cost per $1 \mathrm{~m}^{2}$ for selected façade finishing technologies Source: own research.

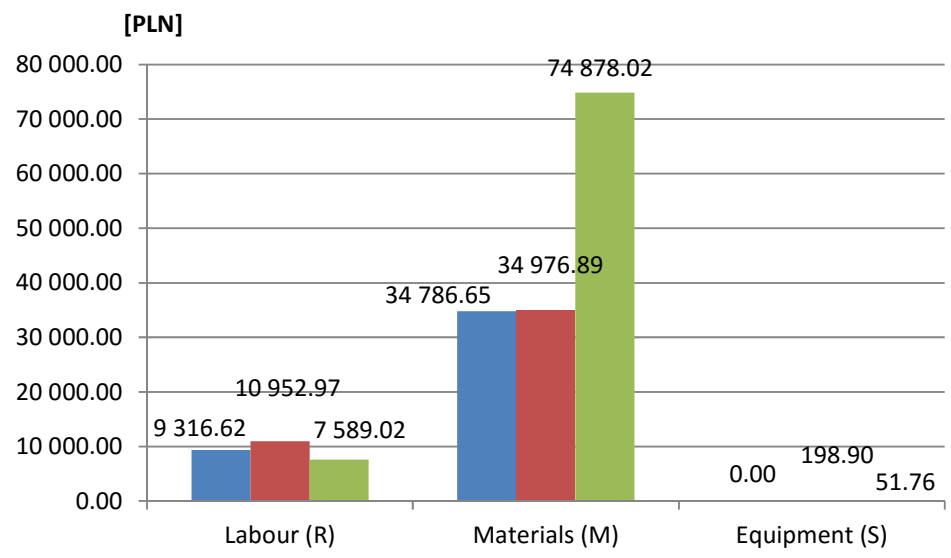

Figure 4. Comparison of the elements of direct cost according to the variants Source: own research. 
costs in other technologies more than twice. At the same time, the price of labour (PLN 7,589.02) is much lower for variant III than for its competitors. When it comes to the cost of equipment, only variant I and variant II generate costs in this matter (Figure 4).

\section{A MULTI-CRITERIA ANALYSIS FOR SELECTED FAÇADE FINISHING TECHNOLOGIES}

The wide applications of multi-criteria tools facilitating decision making in the construction industry in Poland were presented, for example, in Antuchevičiene et al. (2010), Marler and Arora (2004), Szwabowski and Deszcz (2001).

The methods of a multi-criteria comparative analysis include a class of algorithms that create a scalar whose numerical value becomes a synthetic evaluation index - so-called "mathematical methods" (Szwabowski \& Deszcz, 2001). The corrected summation index is the most frequently used discrete multi-criteria method (Trzaskalik, 2014). The application of the synthetic evaluation indices requires a division of the evaluation criteria into stimulants which are positively correlated with the dependent variable, and negatively correlated destimulants.

To enable the comparison and evaluation of the variants, the chosen evaluations of the criteria should be given dimensionless quantities, due to which it is possible to compare not only the quantitative but also the qualitative features.

The procedure involves three steps:

1. determining the corrected values of criteria evaluations for individual variants (stimulant, destimulant),

2. determining the coded values of criteria evaluations for individual variants, determining the corrected summation index $J_{i}$ according to formula (1).

$$
J_{i}=\sum_{j=1}^{m}\left(z_{i j} \cdot v_{j}\right)
$$

where:

$J_{i}$ - the synthetic evaluation of the $i$-th variant;

$m$ - the number of criteria;

$z_{i j}$ - the coded measure of the $i$-th variant in relation to $j$-th criterion;

$v_{j}$ - the weight of the $j$-th criterion.

To perform the multi-criteria analysis the authors proposed five criteria:

- cost per square meter - expressed in PLN; destimulant,

- frost resistance - represented by a number within the range 1-5, where 1 is the worst and 5 is the best; stimulant,

- maintenance possibility - represented by a number within the range 1-5, where 1 is the worst and 5 is the best; stimulant. It is important to be able to maintain the façade easily,

- warranty period - expressed in years; stimulant. The period during which repairs of any damage or defects caused by improper execution are the responsibility of the contractor,

- assembly time per square meter - expressed in hours; destimulant.

To avoid subjective assessment and determine the importance of each criterion a survey was performed. The respondents included investors and contractors. The way of the 
survey execution was based on Crum (1973), involving a simple method of comparing each factor with others. The total number of points that the most important criterion can receive is equal to maximally $n-1$, where $n$ is the number of criteria.

The final weight of each criterion is equal to the decimal fraction in which the numerator is equal to the total number of points received by a given criterion and the denominator is equal to the sum of points received by the 5 chosen criteria ( 279 points); for instance, the cost per $1 \mathrm{~m} 2$ achieved 69 points per total sum of 279 - it gives the weight equal to 0.247 . The values of weights for all 5 criteria are presented in Table 2 and conclude the first step of the procedure.

Table 2. Weights of criteria used in multi-criteria analysis

\begin{tabular}{|c|l|c|c|c|}
\hline No. & \multicolumn{1}{|c|}{ Criterion } & Evaluation & Sum & Weight \\
\hline 1 & Cost per $1 \mathrm{~m}^{2}[\mathrm{PLN}]$ & destimulant & 69 & 0.247 \\
\hline 2 & Frost resistance [1-5] & stimulant & 58 & 0.208 \\
\hline 3 & Maintenance possibility [1-5] & stimulant & 54 & 0.194 \\
\hline 4 & Warranty period [years] & stimulant & 49 & 0.176 \\
\hline 5 & Assembly time per $1 \mathrm{~m}^{2}[\mathrm{~h}]$ & destimulant & 49 & 0.176 \\
\hline \multicolumn{2}{|r|}{$\Sigma$} & 279 & 1.000 \\
\hline
\end{tabular}

Source: own research.

To compare technologies one has to use some methods of data coding, because it is impossible to equate such specific factors as price and time. To encode the data four different methods were used to maximise the objectivity of the result, based on Szwabowski and Deszcz (2001): standardisation method, normalisation method, Neumann - Morgenstern method and Pattern method. For each method the weights of criteria remain constant.

The process of coding and determining the corrected summation index is presented only for the standardisation method. For the remaining items the results obtained are provided. A detailed description of the methods used can be found in Szwabowski and Deszcz (2001) or Dodgson et al. (2009).

According to Szwabowski and Deszcz (2001), the essence of the standardisation method is to replace the partial measurement $x_{i j}$ by the deviation from the average value of the partial measures for all variants according to the criterion $K_{j}$ related to the calculated values of standard deviation. Values are encoded, or standardised (Table 3), using the following formulas:

$$
\begin{gathered}
s^{2}=\frac{\left(x_{1}-\bar{x}\right)^{2}+\left(x_{2}-\bar{x}\right)^{2}+\cdots+\left(x_{n}-\bar{x}\right)^{2}}{n} \\
s=\sqrt{s^{2}}
\end{gathered}
$$

For stimulants:

$$
z_{i j}=\frac{x_{i j}-\overline{x_{j}}}{s_{j}}
$$


For destimulants:

where:

$$
z_{i j}=(-1) \frac{x_{i j}-\overline{x_{j}}}{s_{j}}
$$

$n$ - number of variants;

$s^{2}$ - variance;

$s$ - standard deviation;

$\overline{x_{j}}$ - mean value.

The values of particular criteria and their average values are presented in the form of a matrix in Table 3.

Table 3. Initial matrix for standardisation method

\begin{tabular}{|l|c|c|c|c|c|}
\hline \multirow{2}{*}{\multicolumn{1}{|c|}{ Variants }} & \multicolumn{3}{|c|}{ Stimulants* } & \multicolumn{2}{c|}{ Destimulants } \\
\cline { 2 - 6 } & $\begin{array}{c}\text { Warranty } \\
\text { period } \\
\text { [years] }\end{array}$ & $\begin{array}{c}\text { Frost } \\
\text { resistance } \\
{[\mathbf{1 - 5}]}\end{array}$ & $\begin{array}{c}\text { Maintenance } \\
\text { possibility } \\
{[\mathbf{1 - 5}]}\end{array}$ & $\begin{array}{c}\text { Cost per } \\
\mathbf{1} \mathbf{~ m}^{\mathbf{2}} \\
{[\mathbf{P L N}]}\end{array}$ & $\begin{array}{c}\text { Assembly } \\
\text { time per } \\
\mathbf{1} \mathbf{~ m}^{\mathbf{2}} \text { [h] }\end{array}$ \\
\hline Variant I - clinker brick & 30 & 4 & 4 & 278.86 & 2 \\
\hline Variant II - concrete brick & 3 & 5 & 5 & 304.97 & 1.5 \\
\hline Variant III - composite panels & 10 & 4 & 4 & 475.92 & 0.25 \\
\hline Average value & 14.33 & 4.33 & 4.33 & 353.25 & 1.25 \\
\hline
\end{tabular}

Source: own research (*based on information from commercial bulletins of materials producers).

Table 4. Standardised matrix

\begin{tabular}{|l|c|c|c|c|c|c|c|}
\hline \multirow{2}{*}{ Variants } & \multicolumn{3}{|c|}{ Stimulants } & \multicolumn{2}{c|}{ Destimulants } & $\begin{array}{c}\text { Summary } \\
\text { indicators }\end{array}$ & \multirow{2}{*}{$\begin{array}{c}\text { Evalua- } \\
\text { tion }\end{array}$} \\
\cline { 2 - 7 } & $\begin{array}{c}\text { War- } \\
\text { ranty } \\
\text { period } \\
\text { [years] }\end{array}$ & $\begin{array}{c}\text { Frost } \\
\text { re- } \\
\text { sistance } \\
{[\mathbf{1 - 5}]}\end{array}$ & $\begin{array}{c}\text { Mainte- } \\
\text { nance possi- } \\
\text { bility } \\
{[\mathbf{1 - 5}]}\end{array}$ & $\begin{array}{c}\text { Cost per } \\
\mathbf{1} \mathbf{~ m}^{2} \\
{[\mathrm{PLN}]}\end{array}$ & $\begin{array}{c}\text { Assembly } \\
\text { time per } \\
\mathbf{1} \mathbf{~ m}^{\mathbf{2}}[\mathrm{h}]\end{array}$ & $J_{i}$ & \\
\hline $\begin{array}{l}\text { Variant I } \\
\text { clinker brick }\end{array}$ & 1.369 & -0.707 & -0.707 & 0.851 & -1.019 & -0.012 & 2 \\
\hline $\begin{array}{l}\text { Variant II } \\
\text { concrete brick }\end{array}$ & -0.991 & 1.414 & 1.414 & 0.552 & -0.340 & 0.471 & 1 \\
\hline $\begin{array}{l}\text { Variant III } \\
\text { composite panels }\end{array}$ & -0.379 & -0.707 & -0.707 & -1.404 & 1.359 & -0.458 & 3 \\
\hline Importance & 0.176 & 0.208 & 0.194 & 0.247 & 0.176 & & \\
\hline
\end{tabular}

Source: own research.

The conducted calculations and Table 4 show that Variant II - dry façade from concrete brick has the best evaluation. The results of the multi-criteria analysis for the other methods of encoding are presented in Table 5.

Thus, a question arises about the type of technology to choose eventually. To provide an answer, the authors decided to develop a coefficient taking into account the results from all four methods simultaneously. This coefficient is simply obtained by summing up the 
Table 5. Matrix encoded using different methods

\begin{tabular}{|c|c|c|c|c|c|c|c|}
\hline \multirow[b]{2}{*}{ Variants } & \multicolumn{3}{|c|}{ Stimulants } & \multicolumn{2}{|c|}{ Destimulants } & \multirow{3}{*}{\begin{tabular}{|c|}
$\begin{array}{c}\text { Summary } \\
\text { indicators }\end{array}$ \\
$y$ \\
\\
$J_{i}$
\end{tabular}} & \multirow{3}{*}{ Evaluation } \\
\hline & $\begin{array}{c}\text { Warranty } \\
\text { period } \\
\text { [years] }\end{array}$ & \begin{tabular}{|c|} 
Frost \\
resistance \\
{$[1-5]$}
\end{tabular} & $\begin{array}{c}\text { Maintenance } \\
\text { possibility } \\
{[1-5]}\end{array}$ & $\begin{array}{c}\text { Cost per } \\
1 \mathrm{~m}^{2} \\
{[\mathrm{PLN}]}\end{array}$ & $\begin{array}{c}\text { Assembly } \\
\text { time per } \\
1 \mathrm{~m}^{2}[\mathrm{~h}]\end{array}$ & & \\
\hline $\begin{array}{l}\text { Importance of } \\
\text { criteria }\end{array}$ & 0.176 & 0.208 & 0.194 & 0.247 & 0.176 & & \\
\hline \multicolumn{8}{|c|}{ Normalization method } \\
\hline $\begin{array}{l}\text { Variant I } \\
\text { clinker brick }\end{array}$ & 1.000 & 0.800 & 0.800 & 1.000 & 0.125 & 0.767 & 1 \\
\hline $\begin{array}{l}\text { Variant II } \\
\text { concrete brick }\end{array}$ & 0.100 & 1.000 & 1.000 & 0.914 & 0.167 & 0.675 & 3 \\
\hline \begin{tabular}{|l|} 
Variant III \\
composite panels
\end{tabular} & 0.333 & 0.800 & 0.800 & 0.586 & 1.000 & 0.701 & 2 \\
\hline \multicolumn{8}{|c|}{ Neumann - Morgenstern method } \\
\hline $\begin{array}{l}\text { Variant I } \\
\text { clinker brick }\end{array}$ & 1.000 & 0.000 & 0.000 & 1.000 & 0.000 & 0.423 & 2 \\
\hline $\begin{array}{l}\text { Variant II } \\
\text { concrete brick }\end{array}$ & 0.000 & 1.000 & 1.000 & 0.868 & 0.286 & 0.667 & 1 \\
\hline \begin{tabular}{|l|} 
Variant III \\
composite panels
\end{tabular} & 0.259 & 0.000 & 0.000 & 0.000 & 1.000 & 0.222 & 3 \\
\hline \multicolumn{8}{|c|}{ Pattern method } \\
\hline $\begin{array}{l}\text { Variant I } \\
\text { clinker brick }\end{array}$ & 0.698 & 0.308 & 0.308 & 0.400 & 0.097 & 0.362 & 1 \\
\hline $\begin{array}{l}\text { Variant II } \\
\text { concrete brick }\end{array}$ & 0.070 & 0.385 & 0.385 & 0.366 & 0.129 & 0.280 & 3 \\
\hline \begin{tabular}{|l|} 
Variant III \\
composite panels
\end{tabular} & 0.233 & 0.308 & 0.308 & 0.234 & 0.774 & 0.359 & 2 \\
\hline
\end{tabular}

Source: own research.

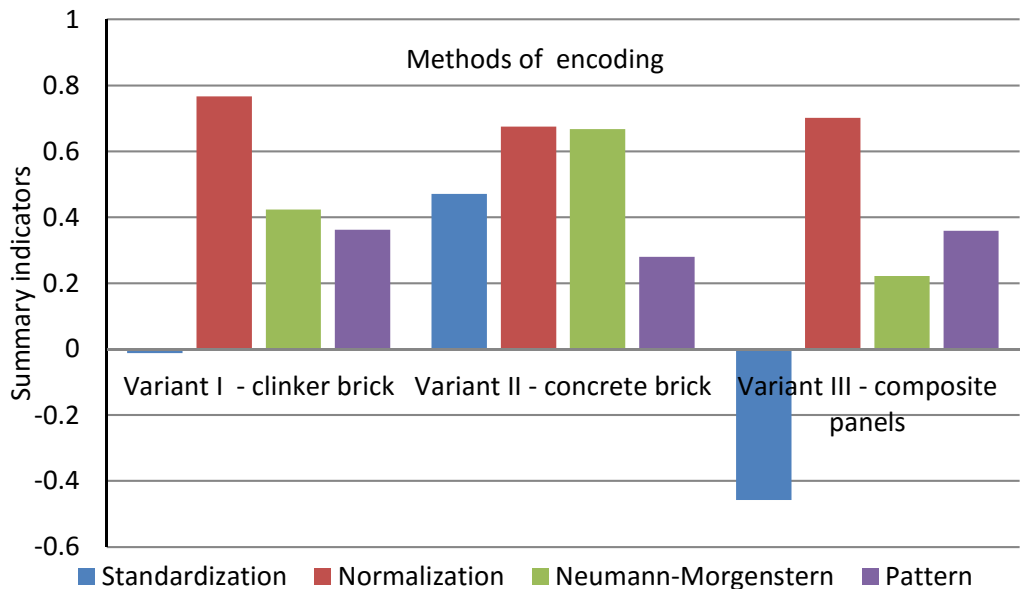

Figure 5. Comparison of multi - criteria analysis results according to the encoding methods Source: own research. 
points awarded for the places that technologies received according to each encoding method. 3 points were assigned for the 1st place, 2 points for the 2 nd and 1 point for the 3rd place. The results obtained in this way (Table 6) show that ultimately clinker brick seems to be the best solution.

Table 6. Final evaluation of selected façade technologies

\begin{tabular}{|l|c|c|c|c|c|c|}
\hline \multicolumn{1}{|c|}{ Variants } & $\begin{array}{c}\text { Standardisation } \\
\text { method }\end{array}$ & $\begin{array}{c}\text { Normalisation } \\
\text { method }\end{array}$ & $\begin{array}{c}\text { Neumann- } \\
\text { Morgenstern } \\
\text { method }\end{array}$ & $\begin{array}{c}\text { Pattern } \\
\text { method }\end{array}$ & $\begin{array}{c}\text { Total } \\
\text { sum }\end{array}$ & $\begin{array}{c}\text { Final } \\
\text { evaluation }\end{array}$ \\
\hline $\begin{array}{l}\text { Variant I } \\
\text { masonry façade } \\
\text { from clinker brick }\end{array}$ & 2 & 3 & 2 & 3 & 10 & 1 \\
\hline $\begin{array}{l}\text { Variant II } \\
\text { dry façade from } \\
\text { concrete brick }\end{array}$ & 3 & 1 & 3 & 1 & 8 & 2 \\
\hline $\begin{array}{l}\text { Variant III } \\
\text { dry façade from } \\
\text { composite panels }\end{array}$ & 1 & 2 & 1 & 2 & 6 & 3 \\
\hline
\end{tabular}

Source: own research.

\section{CONCLUSIONS}

The paper contains a comparative analysis of three variants of façade finishing technologies for a one-storey commercial building. The building has an area equal to $191.7 \mathrm{~m}^{2}$ of walls to perform. This value was needed to prepare the bill of quantities and cost estimate for each technology. Due to the lack of catalogues related to the selected technologies, the authors used other catalogues by analogy. On the basis of cost analysis for all three technologies it can be concluded that the cheapest is the façade made of clinker bricks (PLN 278.86 per $1 \mathrm{~m}^{2}$ ). Variant III, dry façade from composite panels, is the most expensive one (PLN 475.92 per $1 \mathrm{~m}^{2}$ ).

To select the best among the tree facade technologies proposed the multi-criteria analysis was conducted. Five criteria were used to assess the variants discussed: the warranty period, cost frost resistance, maintenance possibility, cost per $1 \mathrm{~m}^{2}$ and assembly time per $1 \mathrm{~m}^{2}$. Four different methods of encoding data were used. Depending on the method, different results were obtained. They show that a multi-criteria analysis depends strongly on the choice of the weights of the criteria. Also the methods of data encoding play an important role. The authors proposed a coefficient taking into account the results from all four methods simultaneously. This coefficient is simply obtained by summing up the points awarded for places that technologies received according to each encoding method.

The results obtained show that ultimately the best solution is a masonry façade from clinker brick. It should be mentioned that this variant was also the cheapest but the weight of criterion: costs per $1 \mathrm{~m}^{2}$ was the highest. The advantages of clinker brick include the following: durability, ease of maintenance, elegant appearance of the façade, very good acoustic properties, high frost resistance, fire and weather resistance, high water vapour permeability, low porosity, low water absorption and resistance to pollution. 


\section{REFERENCES}

Antuchevičiene, J., Zavadskas, E. K., \& Zakarevičius, A. (2010). Multiple criteria construction management decisions considering relations between criteria. Technological and Economic Development of Economy, 16(1), 109-125.

Bojęś, A. (2000). Aspekty architektoniczne kształtowania budynków użyteczności publicznej z lekkimi ścianami osłonowymi nowej generacji. Kraków: Politechnika Krakowska.

Chow, T.T., He, W., \& Ji, J. (2007). An experimental study of facade-integrated photovoltaic/waterheating system. Applied Thermal Engineering, 27(1), 37-45.

Crum, L. W. (1973). Analiza wartości. Warszawa: Państwowe Wydawnictwo Ekonomiczne.

Dodgson, J. S., Spackman, M., Pearman, A., \& Phillips, L. D. (2009). Multi-criteria analysis: a manual. Department for Communities and Local Government: London.

Gratia, E., \& De Herde, A. (2007). The most efficient position of shading devices in a double-skin facade. Energy and Buildings, 39(3), 364-373.

Hien, W. N., Liping, W., Chandra, A. N., Pandey, A. R., \& Xiaolin, W. (2005). Effects of double glazed facade on energy consumption, thermal comfort and condensation for a typical office building in Singapore. Energy and Buildings, 37(6), 563-572.

Kibert, C. J. (2008). Sustainable construction: green building design and delivery. Hoboken, NJ: John Wiley \& Sons.

Komar, B., \& Tymkiewicz, J. (2006). Elewacje budynków biurowych. Funkcja, forma, percepcja., Gliwice: Wydawnictwo Politechniki Śląskiej.

Marler, R. T., \& Arora, J. S. (2004). Survey of multi-objective optimization methods for engineering. Structural and multidisciplinary optimization, 26(6), 369-395.

Perini, K., \& Rosasco, P. (2013). Cost-benefit analysis for green façades and living wall systems. Building and Environment, 70, 110-121.

Shameri, M. A., Alghoul, M. A., Sopian, K., Zain, M. F. M., \& Elayeb, O. (2011). Perspectives of double skin façade systems in buildings and energy saving. Renewable and Sustainable Energy Reviews, 15(3), 1468-1475.

Schoch, O. (2006). My building is my display. In eCAADe Proceedings, 6, 610-616.

Szwabowski, J., \& Deszcz, J. (2001). Metody wielokryterialnej analizy porównawczej. Podstawy teoretyczne i przykłady zastosowań w budownictwie., Gliwice: Wydawnictwo Politechniki Śląskiej.

Trzaskalik, T. (2014). Wielokryterialne wspomaganie decyzji. Przegląd metod i zastosowań, Zeszyty Naukowe Politechniki Ślq̨skiej, seria: Organizacja i Zarzqdzanie, Z. 74, 2014, 239-263.

Wiethoff, A., \& Gehring, S. (2012). Designing interaction with media façades: a case study. In Proceedings of the Designing Interactive Systems Conference, 308-317.

Young, M.E., Urquhart, D.C.M., \& Laing, R. A. (2003). Maintenance and repair issues for stone cleaned sandstone and granite building façades. Building and Environment, 38(9), 1125-1131.

Zieba, M., Belniak, S., \& Gluszak, M., (2013). Demand for sustainable office space in Poland: the results from a conjoint experiment in Krakow, Property Management, 31(5), 404-419. 


\section{Authors}

The contribution share of authors is equal and amounted to $50 \%$ each of them.

\section{Agnieszka Leśniak}

PhD., Eng., assistant professor at Cracow University of Technology, Institute of Construction and Transportation Engineering \& Management. Her main research interests are focused on: construction management, cost modelling, building procurement, bidding and artificial intelligence. Correspondence to: Agnieszka Leśniak, Cracow University of Technology, Faculty of Civil Engineering, Institute of Construction and Transportation Engineering \& Management, ul. Warszawska 24, 31-155 Kraków, Poland, e-mail: alesniak@izwbit.pk.edu.pl

\section{Jakub Balicki}

Eng., student of Cracow University of Technology. His main research interests are focused on: construction management, cost modelling and modern technologies in civil engineering.

Correspondence to: Jakub Balicki - student of L-3, Cracow University of Technology, Faculty of Civil Engineering, Institute of Construction and Transportation Engineering \& Management, ul. Warszawska 24, 31-155 Kraków, Poland, e-mail: jakbalicki@gmail.com

\section{Acknowledgements and Financial Disclosure}

The authors would like to thank the anonymous referees for their useful comments, which allowed to increase the value of this article.

\section{Copyright and License}

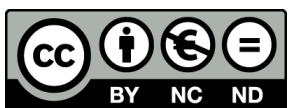

This article is published under the terms of the Creative Commons Attribution - NonCommercial - NoDerivs (CC BY-NC-ND 3.0) License http://creativecommons.org/licenses/by-nc-nd/3.0/ 